\title{
Teaching Translation at the university level with Reference to the Department of English, College of Languages, University of Baghdad: Difficulties and Remedies
}

\author{
Munthir Manhal Mohammed \\ Department of English
}

Al-Israa university college, Baghdad, Iraq

\begin{abstract}
Teaching translation is a two-fold question; the first phase of the question refers to whether or not the translation is teachable as a subject in class. The second phase deals with identifying the methodological approaches of teaching /learning a foreign language in translation. Research has demonstrated that learners of a foreign language do refer to their mother tongue to aid the process of acquiring a second language or in other words, they translate silently. Translation into another language can help them systematize and rationalize the learning mechanism that is used. In other words, translation is present in the process of learning a foreign language. Moreover, it is necessary to differentiate between teaching translation as an academic subject included in the curriculum of the departments of English and teaching translation for professional translators. This paper addresses itself to the process of teaching translation to the students who are going to get their BA in English, not in translation. The researcher takes the department of English, College of Languages, University of Baghdad as a case study to diagnose the difficulties and to suggest remedies for them. The curriculum of the English department incorporates translation from the second-stage to the forth-one with different aims, topics and hours per week. The paper sheds light on several relevant topics such as: is translation a science or a craft? The issue of teachability, and the methods of teaching.
\end{abstract}

Keywords: craft, curriculum, program, science, teaching, teachability, translating

Cites as: Mohammed, M. M. (2019). Teaching Translation at the university level with Reference to the Department of English, College of Languages, University of Baghdad: Difficulties and Remedies. Arab World English Journal for Translation \& Literary Studies 3 (4) DOI: http://dx.doi.org/10.24093/awejtls/vol3no4.8 